\title{
Hepatic Arteriovenous Malformation
}

National Cancer Institute

\section{Source}

National Cancer Institute. Hepatic Arteriovenous Malformation. NCI Thesaurus. Code C35611.

An abnormal connection between arteries and veins characterized by the absence of intervening capillaries in the liver. 